\title{
Patrimônio Relacional: Identidade e Alteridade no Universo das Imagens Técnicas
}

Felipe Loureiro

Universidade Federal do Rio de Janeiro (UFRJ, Brasil

loureiro.fgsf@gmail.com
DOI: https://doi.org/10.18472/cvt.21n1.2021.1926 Redalyc: http://www.redalyc.org/articulo.oa? id $=115466307012$

\section{APresentaÇÃo}

"Eu não vivo no passado. O passado vive em mim". Paulinho da Viola

Os artigos que compóem este dossiê tratam de temas muito diferentes, e o fazem a partir de abordagens aparentemente muito diversas. No entanto, os textos aqui reunidos expressam, cada um à sua maneira, uma disposição comum que move esta nova fase do CVT, e que está ancorada em alguns conceitos fundamentais.

O primeiro destes conceitos compreende algo que temos chamado, em textos produzidos e publicados recentemente[1], de "patrimônio relacional", ou de "uma abordagem relacional do patrimônio". Em síntese, partimos da ideia de que o valor patrimonial de qualquer artefato, saber ou processo reside na relação que diferentes indivíduos construíram, seguem construindo e seguirão a construir com este "objeto”. O valor patrimonial não reside, portanto, no objeto em si, mas - literalmente - na relação entre o sujeito e o objeto. Logo, ao eliminar ou modificar substancialmente um destes atores, se estará modificando - e arriscando destruir - este valor, que é necessariamente uma "obra conjunta".

Esta ideia está ancorada principalmente nas reflexões de Martin Buber acerca das relações Eu-Tu e Eu-Isso, que têm servido como uma das principais lentes interpretativas para as discussões promovidas no âmbito da atuação do Laboratório Tecnologias, Diálogos e Sítios (LTDS)[2] - incluindo esta nova fase do CVT. Em textos e discussões anteriores, esta referência central foi relacionada e cruzada com conceitos desenvolvidos por outros autores, como a distinção entre efeitos de sentido e efeitos de presença - proposta por Hans Ulrich Gumbrecht - e os textos de Hans Belting acerca da experiência de diferentes tipos de imagens. No entanto, para além das referências teóricas e da tentativa de sistematização destes debates e reflexões através da produção de artigos "científicos" - e de uma futura tese de doutorado -, confesso que até o momento sigo retornando constantemente a uma fonte não muito acadêmica. Esta declaração do compositor Paulinho da Viola ainda me parece ser a melhor síntese da abordagem acerca do patrimônio que temos desenvolvido ao longo dos últimos anos:

"Eu tenho a sensação de que tudo o que eu vivi, tudo o que eu experimentei, está vivo em mim. Eu não vivo no passado, é o passado que vive em mim. Quando você se sensibiliza com uma obra feita há 300 anos, se ela lhe toca, lhe emociona, é porque ainda está viva. Tudo para mim é hoje e agora. Eu ouço obras do Pixinguinha e sei que elas foram feitas no século passado. Eu vivo aquilo. Ela não só me emociona, mas é como se fizesse parte do meu ser. Esse tempo é o tempo da minha vida" (Paulinho da Viola in Dávila, 2004).

Para Paulinho da Viola, a música de Pixinguinha estão tão viva hoje quanto estava antes da morte do compositor - talvez esteja inclusive ainda mais viva, já que vem acumulando "valor patrimonial” não só a cada novo ouvinte, mas a cada nova audição. Uma obra como esta não está acabada simplesmente porque seu autor morreu; ela segue viva, dinâmica, em constante transformação. É desta forma que o Prof. Antonio Capestro compreende as cidades, e sua contribuição para este dossiê aponta para a necessidade de se compreender o caráter dinâmico destes lugares, argumentando que qualquer intervenção que busque "congelar" a forma e os usos de uma cidade estará indo de encontro à sua essência. Para realmente preservar, é preciso intervir e modificar. Mesmo que repleta de boas intenções, uma preservação que busque isolar o objeto de seu contexto 
não o estará protegendo, mas sim destruindo o valor patrimonial que reside na relação entre este objeto e os sujeitos que o valorizam - "Quando uma coisa não me interessa, não me toca, pra mim ela morreu." (Paulinho da Viola in Dávila, 2004). Assim, o Prof. Capestro defende uma valorização não só do patrimônio em si, mas também do "patrimônio do projeto", ou seja, dos processos dinâmicos, abertos e muitas vezes imprevisíveis e inconclusivos que levaram à configuração de artefatos e sítios que identificamos como "patrimônio".

As cidades expressam de forma muito clara o dinamismo do patrimônio, que pode ser ainda mais significativo no caso do patrimônio imaterial. No artigo escrito por Luis Torres-Yepez e pelo Prof. Khaldoun Zreik, podemos ver como esta fluidez permite que práticas e conhecimentos tradicionais, cultivados e aperfeiçoados ao longo de séculos, possam ser reapropriados - e em alguns casos literalmente apropriados - por companhias que "consolidam" estas tradições na forma de patentes. Assim, um bem imaterial, dinâmico e vivo é transformado em algo concreto e legalmente limitado, para que possa então ser explorado comercialmente. Neste caso específico, o artigo também mostra como as tecnologias digitais podem ser úteis não só na pesquisa acerca da apropriação destes conhecimentos tradicionais mas também no mapeamento e interpretação das interações entre os diversos atores envolvidos neste processo. $\mathrm{O}$ uso destas ferramentas aponta para outra referência central nos debates promovidos pelo LTDS: os conceitos de aparelho e imagem técnica, desenvolvidos por Vilém Flusser[3]. Os gráficos apresentados no artigo são imagens técnicas produzidas automaticamente através do processamento dos dados coletados - neste caso, debates sobre o tema do uso e apropriação de medicamentos tradicionais no Twitter -, e oferecem portando uma visualização de um fenômeno essencialmente intangível, possibilitando novas formas de análise. Esta visualização permite, por exemplo, registrar de forma tangível as discussões que expressam e alimentam o caráter dinâmico deste tipo de patrimônio, além de identificar tentativas de manipulação deste dinamismo aparentemente orgânico - como o uso de bots que geram publicações automáticas a fim de influenciar o rumo do debate. Neste caso, podemos dizer que um aparelho nos permite desmascarar a atuação de outros aparelhos - um tipo de atuação já consolidado em praticamente todas as interações que permeiam aquilo que Flusser chamou de "universo das imagens técnicas".

Como também já discutimos em textos anteriores, a transição de uma cultura moldada por textos - e pelo senso histórico derivado da forma da escrita linear - para uma nova cultura baseada em imagens técnicas compreende uma revolução ontológica que afeta todas as dimensões da vida contemporânea. No entanto, em meu artigo, busquei traçar um paralelo entre o momento atual e um período razoavelmente distante, a fim de reforçar a noção - incluída no modelo da história cultural apresentado por Flusser - de que este tipo de transformação é recorrente e que a transição para uma nova era não "apaga" a anterior, mas a reinterpreta a partir de uma nova mídia predominante. Assim, a partir de um paralelo proposto por Victor Buchli, analiso os ícones bizantinos à luz dos conceitos flusserianos de aparelho e imagem técnica, compreendendo que o problema enfrentado por artistas e teólogos dos séculos IX e X é similar ao que enfrentamos hoje: como compreender e expressar uma nova forma de estar no mundo, diante da qual os meios de expressão consagrados parecem inssuficientes? Esta reflexão leva, inevitavelmente, a uma discussão acerca do sujeito que busca esta expressão - quem é o Eu que habita o universo das imagens técnicas? Até que ponto os aparelhos - do notebook que estou usando para escrever este texto aos bots que influenciam eleições - são também habitantes deste novo mundo? Voltamos assim à nossa referência inicial: quase 100 anos depois da publicação da obra fundamental de Buber, ainda podemos usar as palavras Eu, Tu e Isso da mesma forma?

Espero que este dossiê possa contribuir para a construção de um espaço no qual esta discussão possa se desenvolver, permanecendo viva nos próximos números do CVT - e não só aqui. Agradeço a disponibilidade e as contribuições dos professores Antonio Capestro e Khaldoun Zreik, de Luis Torres-Yepez e também do Prof. Pedro Marques de Abreu, cujo artigo, publicado no número anterior, antecipa alguns dos temas e, principalmente, o "tom" da discussão que este dossiê busca estimular. 


\section{REFERÊNCIAS}

Dávila, M. (2004, 09 de dezembro). "É tempo de viver: Percepção acelerada do tempo exige reflexão sobre os valores e os vícios da vida”. Folha de São Paulo, disponível em https://www1.folha.uol.com.br/fsp/equilibrio/eq0912 200410.htm

\section{Notas}

[1] Ver LOUREIRO, FELIPE; BARTHOLO, ROBERTO; MATTOS, F.; SANCHEZ, E.. "Da intangibilidade do tangível: por uma abordagem relacional do patrimônio". PAPERS DO NAEA (UFPA), v. 29, p. 321-335, 2020.

[2] Ver LOUREIRO, FELIPE; BARTHOLO, ROBERTO. "Tropical and Eastern Paris: architecture, representation and tourism in Brazil and China". Journal of Tourism and Cultural Change, v. 17, p. 1-13, 2019; LOUREIRO, FELIPE; BARTHOLO, ROBERTO; MATTOS, F.; BARCELOS, F. T.. "Visitar/Acolher: Arquitetura, Turismo e Encontros". REVISTA HOSPITALIDADE, v. 17, p. 95-108, 2020;

[3] Ver LOUREIRO, FELIPE; BARTHOLO, ROBERTO; BURSZTYN, GABRIEL; RIBEIRO, LUIZ. "BIM and Beyond: Architecture and Presence in the Universe of Technical Images". Architectural Theory Review, 2021. 